\title{
MANAGING INTER-DEPARTMENTAL PROJECT DELIVERY TO ENHANCE CUSTOMER SATISFACTION
}

\author{
SANDISO COSA EDOGHOGHO OGBEIFUN \\ JAN-HARM C PRETORIUS
}

\begin{abstract}
A B S T R A C T
The National Department of Public Works and Infrastructure (NDPWI), an agency for infrastructure development in South Africa, provides accommodation and other infrastructure to various public service departments. Each department communicates its infrastructure requirements with the NDPWI. However, there are usually time lags between project briefing and the actual delivery of the infrastructure. Therefore, this article aims to explore the causes of delays and offer solutions to enhance customer satisfaction. The case study method of qualitative research was adopted. Data were collected from the NDPWI regional offices in Bloemfontein, Cape Town and Kimberley, and the professional service department at the head office in Pretoria, among purposively selected participants not below the deputy director level. The Delphi technique was used as an instrument for data collection and complemented during a focus group session. The findings revealed that the major factors contributing to delays included poor planning by the project execution team (PET), ineffective project monitoring and overcentralisation of the decision-making process. The findings, conclusions and recommendations of this research provide useful information for organisational restructuring, the training and continuous retraining of project personnel, especially the project managers. These steps hold the potential for ameliorating the negative effects of delay in the execution of construction projects by the NDPWI.
\end{abstract}

KEY WORDS

customer satisfaction, delays, infrastructure, participants, project execution team

10.2478/emj-2021-0030 pages: $39-56$

\author{
Sandiso Cosa \\ University of Johannesburg, \\ Republic of South Africa \\ ORCID 0000-0002-4126-2803 \\ Corresponding author: \\ e-mail: cosasandiso@gmail.com \\ Edoghogho Ogbeifun \\ University of Johannesburg, \\ Republic of South Africa \\ ORCID 0000-0002-6804-0637
}

Jan-Harm C Pretorius

University of Johannesburg, Republic of South Africa ORCID 0000-0002-2023-749X

\section{INTRODUCTION}

Infrastructure developments involve the active participation of different government departments, with each playing specific and specialised roles. The client (department requiring the infrastructure), in conjunction with other relevant governmental units, scout for suitable land for their proposed infrastructure development. The town-planning services of the city where the development will occur, conduct the geotechnical investigations of the site, provide

Cosa, S., Ogbeifun, E., \& Pretorius J. H. C. (2021). Managing inter-departmental project delivery to enhance customer satisfaction. Engineering Management in Production and Services, 13(4), 39-56. doi: 10.2478/emj-2021-0030 
municipal services, and issue a site clearance certificate as a form of approval so that the project can advance to the planning phase. With this approval, the client approaches the National Department of Public Works and Infrastructure (NDPWI) with their project briefs, strategic goals, and infrastructure requirements, which facilitate the development of the preliminary design and rudimentary estimate. This enables the client to register the project with the National Treasury for funding. If satisfactory, the client receives the document referred to as a "planning instruction" from the National Treasury, authorising the client to commence the project. At this point, the NDPWI appoints a PM to coordinate the project from that point to completion. Furthermore, all relevant consultants (depending on the infrastructure type) are appointed and expected to translate the project briefs, finalise the preliminary design into a final design and produce the tender documents. The procurement unit coordinates the procurement process leading to awarding the contract to the chosen contractor(s). The NDPWI, in collaboration with the consultants, supervises and manages the project development processes until the completed project is delivered to the client.

The NDPWI, South Africa, receives its mandate from the arliament to provide accommodation (buildings) and other infrastructure to various public departments (clients). The NDPWI receives a request from its clients, translates the request to the development of suitable project briefs and the design of the suggested infrastructure. The department moderates the procurement process and oversees the execution of the construction project in consultation with the client. The main clients of the NDPWI include the South African Police Service (SAPS), Department of Defence (DOD), Department of Justice and Constitutional Development (DOJ \& CD), Department of Correctional Services (DCS) and the Department of Home Affairs (DHA).

The NDPWI implements projects through twelve regional offices across the country, coordinated by the central Project Management Office at the head office in Pretoria. This research focused on three regional offices, namely, in Bloemfontein, Cape Town, and Kimberley. The choice of these three regional offices is largely due to economy, time, and proximity to the researcher, who is a staff member of the NDPWI and a resident in the Kimberley regional office. Similarly, SAPS and DOD are used as samples for this study, focusing on project requests registered with the NDPWI between 2016 and 2020 for illustration. Although many projects were registered in each regional office, only two such projects from the SAPS and DOD and their execution status in December

Tab. 1. Sample of selected projects received between 2014 and 2016 (the NDPWI project record in regional offices)

\begin{tabular}{|c|c|c|c|c|}
\hline S/No & INFRASTRUCTURE REQUEST & CLIENT & $\begin{array}{l}\text { DATE WHEN PLANNING } \\
\text { INSTRUCTION WAS ISSUED }\end{array}$ & $\begin{array}{l}\text { EXECUTION STATUS } \\
\text { IN DEC. } 2020\end{array}$ \\
\hline \multicolumn{5}{|c|}{ A: Bloemfontein Regional Office } \\
\hline 1 & $\begin{array}{l}\text { Bloemfontein, De Brug Mobilisation Centre, Area Sup- } \\
\text { port Base: Infrastructure upgrade }\end{array}$ & DOD & $10 / 03 / 2014$ & Planning stage \\
\hline 2 & $\begin{array}{l}\text { Thabong, Bloemfontein East, Training College: Infra- } \\
\text { structure upgrade }\end{array}$ & SAPS & $21 / 12 / 2015$ & Planning stage \\
\hline \multicolumn{5}{|c|}{ B: Cape Town Regional Office } \\
\hline 1 & $\begin{array}{l}\text { Saldanha, Military Base: Construction of Sick Bay Facil- } \\
\text { ity }\end{array}$ & DOD & $15 / 01 / 2014$ & Construction stage \\
\hline 2 & $\begin{array}{l}\text { Cape Town, Wynberg Area Support Base: Western } \\
\text { Cape: Officers Mess: Infrastructure upgrade }\end{array}$ & DOD & $17 / 03 / 2014$ & Construction stage \\
\hline \multicolumn{5}{|c|}{ C: Kimberley Regional Office } \\
\hline 1 & $\begin{array}{l}\text { Jan Kempdorp, } 93 \text { AMMO Depot: Infrastructure up- } \\
\text { grade }\end{array}$ & DOD & $15 / 05 / 2014$ & Construction stage \\
\hline 2 & Kimberley Police Station: Infrastructure upgrade & SAPS & $05 / 10 / 2016$ & Complete \\
\hline
\end{tabular}


2020 are shown in Table 1. Of the six projects, two are still at the planning/design stage, three are at the construction stage, and one has been completed.

Public construction projects that exceed their contract period and allocated budget have been a source of concern for clients (Solomon et al., 2017). The method(s) of executing any infrastructure project has overarching effects on the project success or delay. A construction delay can be referred to as a failure to attain the work's completion within the agreed contract period (Durdyev \& Hosseini, 2019). The sources of delays can be grouped under the following causes, namely, "project, practices, participants and procurement", known as the 4Ps (Ansah \& Sorooshian, 2018, p. 68). Interestingly, delays from project-related factors, practices, participants, and procurement have significant links to the project execution team (PET) members. Therefore, it is imperative to explore the role of PET members in the delay of execution of construction projects by the NDPWI.

In a nutshell, although clients register their requests for infrastructure development early with the NDPWI, the projects are not delivered on time, resulting in infrastructure deficits for the clients, delayed execution of planned programmes, delays in the execution of assigned national development programmes and low levels of customer satisfaction. This paper is an excerpt from a larger research effort that focused on exploring the factors responsible for the delays and suggested a concrete approach on how to ameliorate them. The paper starts with the literature review, which explores the factors responsible for delays in construction projects and the suggested approaches to solving them. It progresses to discuss the adopted research strategy, the multiple-site case study using mixed methods for data collection and analysis. This is followed by the section on the research findings, and the associated discussions against best practices gleaned from the literature. The concluding section provides the conclusions and recommendations. The recommendations include solutions to the factors responsible for delays and identifying areas for further research.

\section{LITERATURE REVIEW}

This section examined the influence of PET members as possible factors responsible for delays in the execution of construction projects. In the context of this paper, PET members mean the client or project representatives, consultants and contractors. Also, the section focuses on the project manager's (PM) role as a client representative or independent entity. It provides information on how to ameliorate the adverse delay effects in the execution of construction projects and gives an overview of project and project stakeholders.

A project can be defined as a temporary endeavour to create a unique product, service, or result (Liu, 2020). The objective of any project is to be executed within specified constraints, commonly referred to as the "iron triangle" of time, cost and quality (Bodea \& Purnus, 2016). According to Ahsan (2018), the five common life stages required to complete the project implementation cycle from needs analysis to full utilisation are "project identification, preparation, appraisal and approval, implementation and evaluation". The American Institute of Architects states that the success of a project delivery method depends on cost, quality, time, safety and how the project meets its intended purpose (Mosly, 2016). Project management involves planning, organising, coordinating, leading, and controlling resources to accomplish the project objective (Mosly, 2016; Hurta et al., 2017). Methods for the infrastructure project execution have overarching effects on the project success or delay. Construction delay can be referred to as a failure to complete works within the agreed contract period due to a deviation from the original plan (Gunduz \& Abu Hassan, 2017; Alsuliman, 2019; Jigeesh \& Rao, 2015). There is a tendency to use more effort to address a deviation rather than review the original plan (Durdyev \& Hosseini, 2019). Therefore, all construction project stakeholders (PET members) need to avoid a deviation by consistently and cooperatively reviewing operational plans. As a PET member, the role of the client is crucial in ameliorating the adverse effects of delay.

Clients, owners, or project sponsors are common terms used to describe individuals, firms or corporate organisations that initiate infrastructure development projects and engage professionals to assist in different execution stages. Construction project clients can be divided into six categories, namely, "contact clients, intermediate clients, primary clients, unwitting clients, indirect clients and ultimate clients" (Cosa, 2020, p. 25). In the context of this research, the primary client is most relevant. Primary clients are individuals, groups of individuals or corporate organisations that own the project and who will pay for the services rendered during the different project phases (Cosa, 2020). To achieve the project objectives, the primary client must provide comprehensive or near-compre- 
hensive briefs to PET members, and PET members must continuously check with the client to confirm or clarify areas of possible discrepancy (Franco \& Nielsen, 2018). It is important to note that whoever is representing the client in the PET team must possess adequate knowledge of the project and be senior enough to take representative decisions on behalf of the client, where necessary. This is necessary to reduce the incidence of delays. Common sources of clientrelated delays include (Ansah \& Sorooshian, 2018) but are not limited to the following:

- Frequent changes in the project scope and specification.

- Change in the leadership that results in requirement changes.

- Adoption of imported ideas without due consideration of the technical implications for construction.

- Disregard for operation and maintenance implications.

- Slow response to enquiries from PET members.

- Slow approvals and sign-off at different stages.

- Lack of prompt payments for services rendered. Therefore, a timely and pragmatic client response is necessary to reduce the adverse effects of delay on the execution of construction projects. Another key stakeholder in the PET team is the Project Manager (PM).

The PM is the single point of reference for achieving project objectives. It is normal practice in the construction industry that the PM is appointed early in the project to provide key management decisions throughout the project life cycle. Depending on the infrastructure type, client preference or procurement system, the PM may be an independent individual or organisation or the lead infrastructure consultant also acting as the PM or a suitably trained and competent in-house professional. PMs are expected to have the necessary technical knowledge, expertise and competence. PMs must demonstrate a variety of competencies that can enhance effective multi-organisational teamwork and communication towards achieving successful project results (Nijhuis et al., 2018). In a typical infrastructure development project, a majority of the problems encountered during the construction phase may have arisen from the actions or inactions during the design phase. Therefore, the PM's technical and managerial competencies have significant impacts on the success of the project (Pourrashidi et al., 2017; Kuchta et al., 2017).

The growing complexity of infrastructure projects has led to the increased employment of specialists in different knowledge areas and contributors to the design.

This requires the effective integration of the knowledge and expertise of the PET members and other associated team members (Nijhuis et al., 2018). Unfortunately, in some building projects, the architects with dominant personalities do not readily accept contributions from other professionals. They can be outright disrespectful to the PM, especially if the PM is not a professional from the engineering or the built environment industry. This wrangling among PET members contributes significantly to delays in project execution (Nijhuis et al., 2018). Therefore, irrespective of the professional background, it is imperative that the PM possesses management competence in leadership, stakeholder management, team development, planning, effective communication, decision-making, cultural awareness and problemsolving. The PM should be analytical, flexible but firm, encourage teamwork and practise effective delegation (Zadeh et al., 2016).

Therefore, in appointing the PM, the client's organisation should ensure that a prospective PM possesses cognate technical capabilities, professional competencies in people skills, team management and project-related capabilities and is proactive. The PM usually serves as an interface between the client and consultants on the one hand and the contractor and consultants on the other hand.

In an infrastructure project, consultants help to translate the client project briefs for the realisation of the proposed infrastructure by developing appropriate work drawings and coordinating the execution of the project. The infrastructure dictates the composition of the relevant professional consultant team. In practice, consultants emerge from different specialist backgrounds but gradually integrate into an interdependent, collaborative, multi-disciplinary projectbased environment, challenging each team member to demonstrate proficiency in project management skills alongside their technical roles in the project. Research efforts by Nijhuis et al. (2018) and Rao (2016) identified the following common sources of delay in the execution of construction projects that can be traced to the role and activities of the consultants:

- Lack of experience.

- Slow development and production of relevant work drawings or their amendments, addressing discrepancies in project documents and specifications.

- Poor communication and coordination with fellow consultants, the client, and contractors. 
- Delays in the effective management of scope change and producing the related amended drawings.

- Inability to conduct effective project inspections, tests, and produce periodic functional reports.

- Frequent changes in the design during construction.

- Late instructions or owner requirements misunderstood by consultants.

Another source of delays from the consultants is the overreliance on the use of design software without adequate adaptations to produce relevant construction details (Rao, 2016). The resulting drawings impair the productivity of the contractors and cause avoidable delays.

Furthermore, the consultants should be proficient in technical roles, team relationships and human resources management to reduce the incidence of delays. The contractor is another critical stakeholder whose activities have overarching effects on the progress of a construction project.

Contractors are important members of the PET. They translate project drawings into the physical edifice to meet the expectation of the client. Their actions or inactions during the project execution periods have significant impacts on achieving project objectives or create avoidable delays. The PM, consultants, and their on-site representatives should follow the contract and work together in different phases of the construction process to reduce the incidence of delays.

In practice, some contractors may intentionally submit low tender figures and unrealistic project execution programmes, all in a bid to win the contract. When this group of contractors assumes responsibility on-site, they begin to raise issues that constitute a variation, which ultimately causes delays, leading to time and cost overruns at the expense of the client (Durdyev \& Hosseini, 2019). The panacea for this group of contractors is to adopt the practice of awarding contracts to the most responsible bid and not the lowest bidder (Gambo et al., 2016). Several sources of contractor-related delays identified by Gambo et al. (2016), Durdyev \& Hosseini (2019) and Rao (2016) are summarised as follows:

- Difficulties in securing additional finance for the execution of the project.

- Poor site management of own staff and subcontractors.

- Poor planning and scheduling.

- Unprofessional construction methods leading to rework due to errors during construction.

- Poor safety practices on site.
Many capital construction projects are awarded to main contractors, but they rely on subcontractors or specialist contractors for the actual execution. The main contractors adopt this practice to reduce their overhead, operating costs, maximise profit and efficient delivery of the project (Tan et al., 2017). In many instances, this approach has positively impacted project delivery. Unfortunately, many of the main contractors focus more on maximising the profit rather than building long-term relationships with subcontractors, which could facilitate improved performance. Other negative attitudes of main contractors that impair cordial relationships with subcontractors, observed by the authors include:

- Main contractors' authoritative attitudes.

- Delayed payment to subcontractors based on the clause "paid when paid".

- Lack of trust between main contractors and subcontractors.

- Subtle transfer of the project risks to the subcontractor.

- At best, subcontractors are "seen and not heard", usually neglected during decision-making processes.

- The main contractor views the suggestions from the subcontractor from the point of cost rather than added value.

Expanding further on relationship difficulties between the main contractor and subcontractors, especially around payment for services rendered, Tan et al. (2017) observed that "Unfortunately, efforts at getting main contractors to deal fairly with their chain of subcontractors have mainly been unsuccessful. Irrespective of the fact that standard contracts stipulate periods within which subcontractors should get paid, such specified periods are repeatedly ignored, with subcontractors often stretched to the limits before getting paid." These negative attitudes demoralise the subcontractors, stifle innovation, reduce productivity, ultimately causing delays and inhibiting improvements in the efficacy of the project delivery process (Pal et al., 2017; Tan et al., 2017). Having discussed the possible causes of delay, it is imperative to explore how to ameliorate construction project delays.

The preceding subsections identified potential factors responsible for delays in the execution of a typical construction project. The literature suggests that the majority of these factors can be ameliorated by and through the office of the PM. In practice, the $\mathrm{PM}$ is the project leader and coordinator of all associated responsibilities for achieving the project objectives. However, PMs will not achieve the project 
objectives without the necessary competencies, such as knowledge, skills and attitude, which are the tools, techniques and practices needed to manage projects. PMs should have the ability to distinguish tools to be used from the project management toolkit to manage and evaluate certain projects after considering their characteristics (Zadeh et al., 2016).

The PM should bear in mind that project success should exceed the "iron triangle" to include client and stakeholder satisfaction, which can be managed effectively through the contextual use of the performance management principle. In management literature, performance measurement is seen as a forerunner to performance management because management follows measurement (Saunila, 2017). Performance management uses the information from performance measurement to effect the necessary changes in an organisation's operational systems, processes and culture. Performance management allows for a symbiotic relationship between leaders and members of the PET by helping to set realistic performance goals. Fillion et al. (2017) suggest that organisations (notably, the PM) should have the ability to cope with rapid changes in construction projects, and the PET members should be capable of responding to the ever-changing demands of customers and global markets. This requires continuous learning together. "Learning organisations are organisations where people continually expand their capacity to create the results they truly desire, where new and expansive patterns of thinking are nurtured, where collective aspiration is set free, and where people are continually learning how to learn together" (Fillion et al., 2017, p. 76). This culture of team learning is central to ameliorating the negative effects of the factors responsible for the delays in the execution of construction projects.

The procurement systems adopted for the execution of a construction project have a significant impact on the performance of the project manager. The three common procurement systems used in the execution of construction projects are the bid-and-build (DBB), design-and-build (DB) and the relationship-based (RB) (Ogbeifun et al., 2018). In the traditional procurement system, the competitive bid method is used for the selection of the PET members (Yap \& Skitmore, 2018). In most cases, the lowest price is used as the criterion for selecting the winner instead of competence, proven previous experience and balanced pricing (Gambo et al., 2016; Deep et al., 2017). If the PM is an independent individual or organisation with an observable weakness, such as being younger and having less professional experience, some consultants on the team may exploit the weakness and make the administration of the project difficult. Alternatively, if the lead consultant in the project also acts as the PM, they might become authoritative, acting as "the judge in their own case" when addressing the shortcomings resulting from the professional lapses of the organisation (Pourrashidi et al., 2017; Durdyev \& Hosseini, 2019). In the design and build (DB) procurement system, the two common approaches and a variant, identified by Baal and Outridge (2020), are:

- Pure DB: both the design and construction team are within the same organisation, commonly referred to as a "consortium". The variant in this approach is where different organisations (consultants and contractors) conglomerate to form a consortium, using the instrument of a memorandum of understanding (MOU).

- Partially integrated DB: the consortium invites other consultants or contractor(s) to execute specific or specialised functions within the project.

The method for selecting the PET members in a DB procurement system significantly influences the role and effectiveness of the PM. If the PM is the lead consultant in the DB consortium, they may behave as a counterpart in the traditional system, "the judge in their own case". On the other hand, if the PM is a client's representative or an independent individual or organisation and not a professional resourced as the lead or other team consultants, the tendency is to undermine the authority of the PM. Conversely, the relationship-based procurement method encourages the symbiotic relationship between the client organisation and the PET in a win-win relationship. Some of the instruments used include Project Partnering (PP), Joint Ventures (JV), Alliance Contracting, Framework Contract (FMC), Early Contractor Involvement (ECI), and Integrated Project Delivery (IPD) (AC) (Aaltonen \& Turkulainen, 2018). The objectives of this system are to encourage the PET members to proactively identify risks and seek the best way(s) to address them before they affect the project (Aaltonen \& Turkulainen, 2018). The client and the executing team jointly set measurable Key Performance Indicators (KPIs) and target timelines. The "purposively" selected PET develops a mutual agreement which encourages the collective sharing of risks and benefits, including the clause for "no blame/no dispute" in their agreement, and harnesses the resources for the project based on the expertise of team members (Aaltonen \& Turkulainen, 2018; Ogbeifun et al., 2018). The system has a thin dividing line between the PM and other 
PET members. Irrespective of the PM, the structure of the relationship-based procurement system can make project management easier for the PM.

In addition to the PM's technical ability, professional competencies, and the adopted procurement system, the client can help the PM execute functions effectively. This can be done publicly by oral and written communications, identifying and asserting the authority of the PM. The client will deliberately refuse any unofficial communications, except through the PM. Thus, other PET members will relate to the PM effectively and reduce the negative effects of delays.

Literature confirms that different stakeholders in the construction industry, notably the project manager, contribute significantly to the delays in the execution of infrastructure projects. Therefore, this research explores the capacity and capabilities of PMs within the NDPWI, the role of senior management in enhancing PMs' ability to ameliorate construction delays and achieve customer satisfaction.

\section{RESEARCH METHOD}

The case study was used as a qualitative research method (Mukhtar et al., 2020) for dealing with specific issues. It allows intense observation, provides opportunities to study various aspects, puts each part in relation to the environment where it operates and tasks the creativity of the researcher to provide "voice to the voiceless" (Braun and Clarke, 2016). This research focused on exploring the factors responsible for the delay in the execution of construction projects by the NDPWI as its specific operational issue. The data for this study were obtained from three regional NDPWI offices (multiple sites) in Cape Town, Bloemfontein, and Kimberley, as well as the headquarters. The data were collected in two stages from pre-quali- fied, purposively selected participants. The process of data collection is explained in subsections 2.2 and 2.3.

\subsection{Population and SAMple}

The population for this research includes all the staff of the NDPWI responsible for infrastructure development in South Africa. However, due to resource and time constraints, the sample of participants was limited to the Kimberley, Bloemfontein, and Cape Town regional offices of the NDPWI, as well as the Professional Services Department at the headquarters in Pretoria. The target sample was 28 participants from the Construction Management, Professional Services, Finance and Supply Chain Management (SCM) Units. The participants were officials at the level of Chief Director, Director and Deputy Director who had spent at least five years in the relevant departments. Initially, 22 personnel accepted the invitation to participate in the research. Five of them were disqualified because four did not complete the information on personal demographics, and one had been in the office for less than five years. The 17 participants who met the pre-qualification criteria continued in the remaining phase of the research exercise. The demographics of the participants are summarised in Table 2.

\subsection{Data Collection}

Two instruments were used for data collection, namely, the Delphi technique and the focus group (FG) session. The first phase of data collection using the Delphi technique sought to identify the factors responsible for the delay in executing the infrastructure projects on behalf of the clients of the NDPWI. The second phase of data collection was aimed at discussing the impact of the factors identified in the first

Tab. 2. Summary of participants' demographics

\begin{tabular}{|c|c|c|c|c|c|c|c|c|c|}
\hline \multirow[t]{2}{*}{ Position } & \multicolumn{3}{|c|}{ QUALIFICATION } & \multicolumn{3}{|c|}{ EXPERIENCE } & \multicolumn{2}{|c|}{ GENDER } & \multirow[t]{2}{*}{ TOTAL } \\
\hline & $\begin{array}{l}\text { Post-grad- } \\
\text { uate }\end{array}$ & $1^{\text {st }}$ degree & Diploma & $6-10$ & $11-20$ & $20+$ & Male & Female & \\
\hline Chief Director & 2 & - & - & 1 & 1 & - & 1 & 1 & 2 \\
\hline Director & 1 & 2 & 1 & 1 & 1 & 2 & 1 & 3 & 4 \\
\hline Deputy Director & 1 & 3 & 2 & 2 & 3 & 1 & 3 & 3 & 6 \\
\hline Chief Architect & 2 & - & - & - & - & 2 & 1 & 1 & 2 \\
\hline Chief Engineer & 1 & - & - & - & - & 1 & 1 & & 1 \\
\hline Architect & 1 & - & - & - & - & 1 & 1 & & 1 \\
\hline Engineer & - & 1 & - & - & - & 1 & 1 & & 1 \\
\hline
\end{tabular}


phase and proffering suitable solutions. These data were collected through the FG session.

The Delphi technique, a "hybrid" of quantitative and qualitative methods, was used for data collection and analysis, and the results were complemented with a focus group (FG) session (Ogbeifun et al., 2016; Ogbeifun et al., 2017). The Delphi technique has many variants, the two most common being the classical and the modified classical Delphi. The difference between the two variants is that in the classical Delphi, participants generate the prospective solutions to the research question in the first round of the exercise, which is usually a qualitative response. In the modified classical Delphi, participants are provided with generic solutions in round one. After the first round of the classical Delphi, the subsequent rounds of data collection run the same course as in the modified classical Delphi and the data collected are treated through a quantitative approach. The classical Delphi technique was used in this study.

The participants of a typical Delphi exercise are commonly referred to as the panel of experts or highly knowledgeable persons in the research subject (Szpilko, 2020). They can be few or as many as possible. They are "purposively, rather than randomly" selected after careful pre-qualification. The geographical location of participants is no hindrance to effective participation in a Delphi exercise (Belton et al., 2019). No participant can be traced to his or her contribution; they can express themselves freely without group pressure or pressure from persons with dominant personality traits (Ogbeifun et al., 2017). The exercise goes through several rounds of data collection, which allow participants to adjust their responses, and the results are refined in these successive rounds of data collection. The research coordinator serves as an unbiased umpire who collates, iterates, and circulates feedback to participants without interference in the process. Depending on the sample size, extensive statistical analysis may be necessary, or the basic computation of the statistical mean and sometimes accompanied with standard deviation (SD) can be used to evaluate consensus. Consensus or equilibrium of opinion is attained when participants no longer change their opinion or the process has attained 51-80 $\%$ agreement on the items in the final list (Belton et al., 2019).

In the first round of the Delphi exercise, the 17 participants who met the pre-qualification criteria were requested to suggest between three and five reasons they observed as causes of delays in the execution of construction projects by the NDPWI (classical
Delphi). After the synthesis of responses from the participants, 106 generic suggestions were listed. The suggestions were whittled down to 89 factors by eliminating the duplication of factors. The list of 89 suggestions was circulated to participants in Round 2, requesting them to score the factors on a five-point Likert scale.

The scores were allocated in terms of importance with 1 denoting not important and 5 denoting extremely important, $(1=$ "not important", $2=$ "important", 3 = "moderately important", 4 = "very important", 5 = "extremely important"). It was agreed that after the analysis, only factors with a score of 3.0 and above would be taken to subsequent Rounds. One participant did not return his response due to workload, and 16 participants submitted responses in Round 2. The exercise went through three rounds of data collection and analysis before achieving equilibrium in Round 3, and 36 factors were identified to be responsible for the delays in the execution of construction projects by the NDPWI. The outcome of the Delphi exercise was taken to the FG session for ratification. The details of the executed Delphi process, analysis and the results are presented in the section on findings and discussion.

\subsection{FOCUS GROUP SESSION}

An FG session is a qualitative method of data collection, rarely used as a stand-alone approach but preferably employed in conjunction with other methods (Varga-Atkins et al., 2017). Compared to a oneon-one interview, an FG session is more cost-effective (Varga-Atkins et al., 2017). The size of a typical FG session is between 4 and 12 participants (Reefke \& Sundaram, 2017; Sierra-Varela et al., 2017). It is possible that in a group larger than 12 , many ideas may be generated, but it may become difficult to manage, especially with dominant characters in the group (Reefke \& Sundaram 2017; Sierra-Varela et al., 2017). When an FG session is used as a complementary tool to other research efforts, first, the FG session reviews, adopts or adapts the conclusions from the previous research exercise (Reefke \& Sundaram, 2017; Strasser, 2017). The FG session evaluates the conclusion, developing practical solutions to the problems identified in the previous research effort (Ogbeifun et al., 2016). In this research, the FG session confirmed the 36 factors developed as reasons responsible for the delays in the execution of construction projects by the NDPWI. They analysed the associated problems and proffered solutions. The synthesis of the solutions led to the 
development of suitable themes, which are discussed in the findings and discussion section.

\subsection{VALIDITY AND RELIABILITY}

The reliability and validity of any research are influenced by the quality of data, the source of data and the analysis method. In this research, the participants who had contributed the data were key stakeholders in the NDPWI involved in infrastructure development. None of the participants was below the deputy director level; they had at least five years of work experience and possessed a blend of educational qualifications, including postgraduate degrees, a bachelor's degree and a diploma. The gender balance of participants was ensured as there were nine males and eight females. This composition provided a high degree of reliability to the data collected. As a tool for data collection, the Delphi technique added to the reliability of the data because the participants' opinions were anonymous and obtained without pressure (Ogbeifun et al., 2017). The result of the Delphi exercise was ratified by the FG session (Ogbeifun et al., 2016). The practice of using different instruments for data collection, akin to the principle of triangulation, helps to improve the reliability and validity of data and the entire research process (Maslach et al., 2018).

\section{FINDINGS AND DISCUSSION}

The two methods or instruments used for data collection are presented in this section together with the results.

\subsection{OUtCome OF THE DelPhi EXercise}

The Delphi exercise went through three rounds of data collection and analysis before it achieved equilibrium. The first round was a qualitative response, where participants provided 106 possible reasons for delays in the execution of approved infrastructure projects by the NDPWI. The initial 106 factors were reduced to
89 and circulated to the participants in Round 2. The participants were invited to rate the factors using the five-point Likert scale, and the statistical mean approach was used to analyse consensus. After the analysis, 84 factors met the requirement of the benchmark of 3.0 and above. Due to similarities in the terminology, the 84 factors were further refined to 36 factors. The 36 factors were recirculated to the participants in Round 3. After the analysis, the 36 factors were retained. At this point, the process had attained equilibrium because participants did not change their opinion, and the exercise was terminated. A careful study of the results showed that most factors responsible for the delays were due to the operations of inhouse personnel, policies, and practices of the NDPWI, as shown in Table 3. Therefore, the participants for the FG session were limited to the strategic leaders from the three regional offices.

The FG session had eight participants, including two Chief Directors, one Director and five Deputy Directors. This figure is within the acceptable limit of 4 to 12 participants recommended by literature (Reefke \& Sundaram 2017; Sierra-Varela et al., 2017). The FG session was conducted through the video conferencing system, which lasted for four hours.

The 36 factors were circulated to the members of the FG session. Their first assignment was to confirm, amend or refute the 36 factors (Reefke \& Sundaram, 2017; Strasser, 2017). All members agreed that the 36 factors aptly represented the causes of delays. Table 4 is an excerpt from the 24 factors contributed by the NDPWI, relating to PM competencies, composed during the Delphi exercise and confirmed in the FG session.

Each factor was discussed, identifying the root causes of the problems, and panel members offered solutions, which facilitated the development of suitable themes. For example, the factors relating to projectmanagement competencies, the discussions on factors 1 and 2 in Table 4 and the synthesis of information that led to identifying suitable themes are used to illustrate the outcome of the FG process. Table 5 provides the discussion on factors 1 and 2 from Table 5 ,

Tab. 3. Classification of factors

\begin{tabular}{|c|c|c|c|c|c|}
\hline \multicolumn{6}{|c|}{ CLASSIFICATION OF RESULTS } \\
\hline Clusters & NDPWI & CONTRACTOR & CONSULTANT & OTHER & TOTAL \\
\hline Number of factors & 25 & 5 & 3 & 3 & 36 \\
\hline Percentage representation & $69.5 \%$ & $13.9 \%$ & $8.3 \%$ & $8.3 \%$ & $100 \%$ \\
\hline
\end{tabular}


Tab. 4. Summary of factors related to PM competencies

\begin{tabular}{|c|l|c|}
\hline S/No & \multicolumn{1}{|c|}{ FACTORS } & SUITABLE THEME \\
\hline 16 & $\begin{array}{l}\text { The lack of work ethic by PMs within the NDPWI - the lack of motivation/poor morale and } \\
\text { no sense of responsibility towards the achievement of goals as a collective }\end{array}$ & \\
\hline 21 & $\begin{array}{l}\text { Incompetent PMs - the lack of leadership and understanding of internal processes in the } \\
\text { department, poor planning, monitoring and poor management of various contracts in the } \\
\text { project }\end{array}$ & PM Competencies \\
\hline 27 & $\begin{array}{l}\text { Insufficient progress monitoring on-site and contractor reporting not delivering to PM. } \\
\text { The lack of work ethic among PMs within the NDPWI - sometimes incorrect estimation of } \\
\text { time and costs }\end{array}$ & $\begin{array}{l}\text { Failure to accomplish the Visit Programme Plan and poor monitoring of execution programme } \\
\text { by the PM }\end{array}$ \\
\hline 36 & $\begin{array}{l}\text { NDPWI Engineering and Architectural teams notified late by the PM regarding their involve- } \\
\text { ment in active projects }\end{array}$ \\
\hline
\end{tabular}

Tab. 5. FG discussions on factors 1 and 2

\begin{tabular}{|c|l}
16 & $\begin{array}{l}\text { The lack of work ethic by PMs within the NDPWI - the lack of motivation/poor morale and no sense of responsibility towards } \\
\text { the achievement of goals as a collective team }\end{array}$
\end{tabular}
Analysis:

- PMs are not recognised for their effort and good performance

- Poor management of resources and work by Senior Managers

- Allocation of duties is inconsistent to boost the morale of under-utilised officials, leaving some PMs over-utilised and others under-utilised

- Management does not enforce the correlation between goods and services and the expenditure on sites

- Poor management of incoming Planning Instructions by the Head of Projects leading to capacity problems in the regions whereas staff who had left is not replaced

Solutions:

- The NDPWI must demand high-performance standards and value from PMs

- The NDPWI Senior Management must enforce consequence management

- Continuous training and development for PMs to improve skills and boost morale

- Enhance teamwork culture and improve communication

Theme:

- PM competencies

31 The lack of work ethic by PMs within the NDPWI - sometimes they provide an incorrect estimation of time and costs.

Analysis:

- There is no accountability and responsibility for PMs and consultants

- PMs are not effectively managing projects from inception until closure

- There is a lack of performance management of PMs by heads of PMs and a lack of performance management of the head of projects by regional managers

- Regional managers do not play an oversight role in the management of projects and during the monthly reporting sessions of the project-management schedule

Solutions:

- Appoint PMs who have at least a Bachelor's degree (including proficiencies in project management, acquired through postgraduate studies or continuous professional development) and 10 years of experience

- PMs must be professionally registered with relevant professional bodies, having a minimum of 6 years post professional registration

- Senior management must enforce consequence management if PMs do not implement contract management

Theme:

- PM competencies 
Tab. 6. Themes and associated clusters

\begin{tabular}{|l|l|l|}
\hline \multicolumn{1}{|c|}{ S/NO } & \multicolumn{1}{|c|}{ THEMES } & \multirow{2}{*}{ ASSOCIATED CLUSTER } \\
\cline { 1 - 2 } 1 & Effective client-management structure & \multirow{2}{*}{ Service provider (NDPWI) related } \\
\hline 2 & Project-management competencies & \\
\hline 3 & Leadership & Consultant related \\
\hline 4 & Systems thinking & Contractor related \\
\hline 5 & Consultant competencies & All the stakeholders \\
\hline 6 & Contractor competencies & \\
\hline 7 & Teamwork & \\
\hline
\end{tabular}

showing the analysis, the solutions proffered by the participants and the developed theme.

A similar approach was adopted in the discussion of 36 factors, which led to the development of the following themes:

1. Effective client-management structure.

2. Project-management competencies.

3. Leadership.

4. Systems thinking.

5. Consultant competencies.

6. Contractor competencies.

7. Teamwork.

The themes were classified into four clusters, as shown in Table 6.

\subsection{Discussion OF FINDINGS}

In this section, the discussion of the research findings will be limited to the themes associated with the factors contributed by the service provider (the NDPWI), namely, effective client-management structure, project-management competencies, leadership and systems thinking. This is because the service provider contributed the highest number of factors responsible for the delays in the execution of the client's construction projects.

\subsubsection{EFFECTIVE CLIENT-MANAGEMENT STRUC- TURE}

There are five models of organisational structure commonly referred to in the literature on organisational structuring, namely "the simple model, the bureaucratic model, the professional model, the adhocratic model, and the divisional model" (Janićijević, 2017, p. 7). The simple model is commonly practised in small firms, led by single individuals who tend to be autocratic leaders, and the bureaucratic model occurs in large companies and public administration departments. Employee participation in decision-making is extremely low in the bureaucratic model. Professionals play a key role in the professional model and the adhocracy model. The fifth - the divisional - model is complex, as it consists of two or more levels of authority. The NDPWI management structure is best described under the bureaucratic model, which is highly formalised with centralised models of administration involving the "top-down-bottom-up" approach.

Based on the FG session, employees and professionals are experiencing loss of autonomy, innovation and are limited to controlled participation in decisionmaking processes (Janićijević, 2017). That is why even senior managers do not see themselves fit to take firm and timely technical decisions during project execution. They are compelled to go through the established hierarchy, which is time-consuming. This leads to a sense of the "lack of urgency" among government officials. Furthermore, FG members believed that the structure strips significant authority from the PM, resulting in general project management delays and reporting defaulting contractors for an appropriate sanction.

\subsubsection{Project-MANAgement Competencies}

Project-management competencies may be divided into three separate elements, such as knowledge, performance and personnel. A successful PM must have the knowledge and insight of technical project features, relationships between team members and project elements (Sharma, 2017). Competency can be defined as skills, attitudes, knowledge and personal characteristics that can be improved with experience, education and training (Oun, 2016). This challenges the PM to adapt the ten Project Management Institute (PMI) knowledge areas, which include "project integration, scope, time, cost, quality, human resource, communication, risk, stakeholder management, and procurement management" (Oun, 2016, p. 31). The implication of the negative factors attributed to the delays in the execution of construction 
projects by the PM becomes clearer when related to the relevant PMI knowledge areas, which are as follow:

- Project integration and human resources. To achieve project integration and the effective use of available human resources in any project, the PM should actively involve all project stakeholders, both internal and external team members. In this research, the late involvement of the in-house technical team (engineers and architects) contributes to the delays in the execution of construction projects. The factor suggesting the PM's "lack of motivation/poor morale and no sense of responsibility towards the achievement of goals" can also be attributed to the lack of early involvement of other relevant team members.

- Communication. As a build-up on (a), PMs lack the skill of and practise in effective communication. This is evident in their lack of understanding of internal processes, communication with senior management, monitoring and evaluation, developing suitable periodic reports as well as the effective coordination of PET members.

- Scope, time, cost and quality. The Delphi exercise identified the PM as "lacking work ethics ... sometimes they provide an incorrect estimation of time and costs". A low competence level in these areas has significant effects on scope change management, the quality of the construction process and, in turn, influences the timely execution of the overall project.

Furthermore, concerted efforts should be made to ameliorate the negative effects of the factors responsible for project delays. This challenges the PM, the coordinator of the PET members and client representative, to imbibe the culture of team learning and contextual use of the concept of performance management (Saunila, 2017; Fillion et al., 2017). Therefore, it is imperative that PMs should undergo periodic training to improve their project-management skills and coordination abilities.

\subsubsection{LEADERSHIP}

Management and leadership literature offers several definitions of the term leadership. The postulations of reference (Davis, 2018) on leadership are being considered here as: a matter of personality, inducing compliance, the exercise of influence, particular behaviours, a form of persuasion, a power relation, an instrument to achieve goals, an effect of interaction, a differentiated role, initiation of struc- ture, and as many combinations of these definitions. These definitions suggest that organisational leaders must acknowledge that a system can only function effectively if its subsystems are fully functional, and employees can support the change if they have been made aware of the changes (Sharma, 2017).

The findings from this research revealed that the factors responsible for the delays in the execution of construction projects, contributed by the leadership style and structure of the NDPWI, can be classified into three groups, namely, process centralisation, performance measurement and performance management.

The practice of process centralisation implies the religious observance of the "top-down-bottom-up" concept of leadership, where the centre exerts control over the operation of the whole organisation. This leadership style does not encourage innovation but produces mere mechanical followership. This research revealed the following factors as evidence of the negative influence of processes over-centralisation:

- Indecision by the NDPWI Management.

- Poor planning by the NDPWI Senior Management.

- Government Officials in constant fear of severe consequences and punishment by Senior Management for taking wrong decisions.

The over-centralisation of the decision-making process inhibits innovation, creates room for indecision, poor planning, and fear among subordinates. However, the "top-down-bottom-up" concept of leadership can be flexible if it allows for inclusive, participatory leadership (Chan et al., 2016); but in an over-centralised system, instructions are communicated from top to lower levels. Response and suggestions are communicated from lower to higher levels. Until approval is received from the senior management, the officers at lower levels cannot act, which in turn causes delay. The leadership style of the persons occupying control positions within the NDPWI structure, at the different levels, determine whether the structure tends towards a strictly bureaucratic model or a suitable modification that allows for a reasonable measure of autonomy and innovations (Chan et al., 2016). Proactive leadership suggests a blend in using two leadership tools of performance measurement and performance management.

In management literature, performance measurement is seen as a forerunner to performance management because management follows measurement after suitable assessments (Mahdi et al., 2020). There are many definitions of Performance Measurement 
(PM), but we refer to two in this research that describe $\mathrm{PM}$ as "the process of quantifying the efficiency and effectiveness of an action" (Ogbeifun, 2018). The Oak Ridge Associated Universities provided a simplistic but practical definition: "Performance measures quantitatively tell us something about our products, services and the processes that produced them; they are a tool to help us understand, manage, and improve what our organisations do" (www.orau.gov). The common features in these definitions are that:

- PM operates with a defined set of measurable indicators of production or work process;

- The indicators are designed to achieve the goals of the organisation;

- The feedback from periodic observations (assessments) are used to improve the production or work process (management).

- The application of the principles and PM practice will enable the NDPWI:

- To determine issues that are critical for the achievement of its infrastructure development goals.

- To determine issues that are critical for the successful delivery of the infrastructure and achieve customer satisfaction.

Though there are many benefits to adopting performance measures, it should be noted that "performance measurement is only a tool, whereas performance improvement is the goal" (RodriguezLabajos et al., 2016). Therefore, in the design of an appropriate performance measuring system, first, identify the characteristic content and structure of the performance measure and the suitable model to drive the implementation. The driving force behind the concept of performance measurement hinges on the timeless adage "you can't manage what you can't measure" and "what gets measured gets done" (Shohet \& Nobili, 2017).

There are several tools or models available for the measurement of the performance of the whole or part of the organisations' operations (Ogbeifun, 2018). A few of them will be mentioned here, such as total quality management (TQM), and the balanced scorecard (BSC) (Okwiri et al., 2018), the business excellence model (BEM), the Capability Maturity Model (CMM), the key performance indicators (KPI) (Rodriguez-Labajos et al., 2016), the just-in-time (JIT) model (Gomes \& Yasin, 2017; Knol et al., 2018), and Six Sigma (Rosa \& Broday, 2018). The objectives of each model are to improve on the current performance to achieve the goals of the organisation (Ogbeifun et al., 2016). Each model has unique variables for meas- uring performance and standard units for the assessment of that performance (Ogbeifun, 2016a). The Balanced Scorecard (BSC) has assumed a prominent position as a tool for performance measurement and management (Rodriguez-Labajos et al., 2016). However, the complexities of data collection, proficiency in statistical analysis and translating the general concept to concrete contextual action have limited the use of BSC for performance measurement (Ogbeifun et al., 2016a).

The quality of results from using any performance measurement tool depends on the development of personally effective individuals committed to a common vision and an emphasis on customer needs (Ogbeifun et al., 2016). This concept of developing personally effective individuals to be committed to the vision of customer satisfaction is crucial because service providers may work as a team or as individuals. Until the individual imbibes the culture of working with the view of customers' satisfaction, having customer satisfaction as a goal may end up as a mere policy statement. Although the implementation of any performance measure may yield immediate, visible improvement, the goal is not a quick fix of things but to develop relationships and processes capable of generating and sustaining quality improvement now and in the future (Ogbeifun et al., 2016). It is an exercise that requires a commitment to succeed and road maps for more effective management (Ogbeifun et al., 2016). Furthermore, other factors that would affect the results include the level of competence, capacity and capabilities of the operating personnel, quality of data and commitment to their analysis.

The objectives of performance measurement will not be achieved without adequate and periodic assessments of actual performance (Ogbeifun, 2018). Performance assessment compares performance results against the expectations of the measuring system in operation (Ogbeifun et al., 2016). The assessments should be timely, accurate and relevant. The exercise should be undertaken in ways easily understood by the actors using the performance measuring system being evaluated (Ogbeifun et al., 2016). The differences in measurements are harnessed in coordinated feedback, and this, in turn, is used to develop suitable strategies for improved performance (Ogbeifun, 2018). Although several performance measurements have been conducted, or their tools utilised, they are not often followed by an effective analysis of results or honest attempts at the improved performance (Ogbeifun et al., 2016). The performance assessment records obtained from the feedback information should be 
subjected to further investigation. Effective analysis of feedback facilitates the identification of the magnitude and source of variance. Feedback can be obtained using the instrument of an individual or group interview, a response to a questionnaire, a focus group session or through the Delphi technique (Ogbeifun et al., 2016). The analysis of the inputs from relevant stakeholders during the feedback exercise should be followed by focus group sessions (Varga-Atkins et al., 2017).

Reflecting on the analysis of findings in Table1 1, and an average of five years after registering a request for infrastructure development with the NDPWI, only one project is completed, three at the different stages of construction and two are still at the planning or design stage. If the leadership of the NDPWI had a performance measurement system in place and performance measures were assessed periodically, the management would have asked relevant questions, identified debilitating problems, and addressed them. Consequently, the department was not responsive to customer needs because the leadership did not seem to be mindful of factors leading to customer satisfaction. In this regard, if the NDPWI should achieve customer satisfaction, the department would have to embrace the three components of performance measurement, performance assessment and performance management.

Performance management uses the information from performance measurement to affect the necessary changes in the operational systems, processes, and culture of an organisation. Performance management allows for a symbiotic relationship between leaders at the strategic and tactical levels in an organisation by helping to set realistic performance goals. The process enables the tactical level leaders to allocate and prioritise resources for achieving the set goals within the stipulated time frame (Lee \& Mouritsen, 2018; Janićijević, 2017; Shao et al., 2017). In the NDPWI organisational structure, the PM is accountable to other senior managers, who oversee their performance and report to others in the higher levels of leadership. The findings from the Delphi exercise and the focus group session revealed that the supervising managers were slow-moving in the performance of their functions, as shown in these factors:

- Poor performance management by PMs, which is not reported by Senior Managers.

- Insufficient monitoring and reporting of contractors who do report to Senior Management.

The performance management process requires demanding progress reports from subordinates, pro- gressive reviews, confirmation or change of current policy or programme directions (Lee \& Mouritsen, 2018). The performance results emanating from the performance measurement tool is shared with all relevant units of the organisation progressively in a collaborative effort of pursuing, achieving, and excelling in the set goals (Janićijević, 2017). Consequently, the contextual application of the suggestion from performance assessment through performance management facilitates progressive performance improvement in any organisation (Shao et al., 2017).

Therefore, the performance management challenges senior management of the NDPWI to set, monitor and evaluate the performance of the PM in every project to ensure that productions are in accordance with the project schedule. Otherwise, proactive measures should be taken to ameliorate delays. According to Shaw (2018), PMs are responsible for planning, organising, coordinating, controlling and directing the execution of the project. The PM demonstrates their skill and competence level in the quality of activities showing the construction process, otherwise known as "Work Breakdown Structure". These activities are represented in the timeline, using the most convenient project or construction management tools, such as Gantt Charts, the Project Evaluation Review Technique (PERT), and the Critical Path Method (CPM). Successful projects are characterised by execution within the given project timeline (Bodea \& Purnus, 2016). The quality of the periodic reports from the PM, performance in terms of time, cost and quality will inform senior managers on the areas of continuous training of the NDPWI PMs, which must be consistent with the recommendation by the Project Management Institute.

\subsubsection{SYSTEMS THINKING}

A learning organisation is characterised by five fundamental disciplines, such as systems thinking, personal proficiency, mental models, shared vision, and team learning. All five disciplines must be developed together. Systems thinking is regarded as the first discipline and a cornerstone of the other disciplines, interlinking them to function as a unit. Systems thinking and other disciplines are joined through a mind shift from seeing parts to seeing wholes (Fillion et al., 2017). According to the FG session, the NDPWI directorates are working in silos with extensive delays caused by the supply chain management (SCM) processes. Although the NDPWI has a mandate from the Parliament to provide accommodation and infra- 
structure to other departments, the implementation of these projects is achieved with the high cost and time overruns due to bureaucracy, conflicting policies, and an overcentralised administration. FG participants observed that the NDPWI is overregulated, resulting in prescripts that are not user-friendly, constant changes and the lack of understanding of supply chain management (SCM) processes by officials, bid committees, consultants, and contractors.

Fillion et al. (2017) suggested that organisations and governments should have the ability to cope with rapid changes and frontline staff capable of responding to the ever-changing demands of customers and global markets. "Learning organisations are organisations where people continually expand their capacity to create the results they truly desire, where new and expansive patterns of thinking are nurtured, where collective aspiration is set free, and where people are continually learning how to learn together" (Fillion et al., 2017, p. 76). For any change to take place, people must be motivated to assist in making the change a reality. Personal proficiency assists in focusing strengths on achieving a successful result for the organisation. The NDPWI managers should provide enabling conditions for people to develop their skills and integrate them into the execution of their given task to achieve the goals of the department. Through open lines of communication, the staff can share the vision of an organisation and integrate a sense of involvement.

Granted that the NDPWI has the mandate of the government to develop infrastructure, the benefiting departments need the infrastructure for the performance of governance for the benefit of the citizens. Nevertheless, the citing and execution of such infrastructure initially or permanently alter the host community's lifestyle. Therefore, it is necessary to build a collaborative relationship with the host community to win their support and buy into the project. Achieving this requires "thinking outside the box" and not overt reliance on the government's authority. The FG session suggested that the NDPWI should engage the collaborative efforts of non-governmental organisations (NGOs) and other government departments to improve on the relationship-building efforts and support from the project host communities, to facilitate smooth project execution.

Team learning is developed from inside the organisation through a dialogue between staff members, and it is buttressed by systemic thinking, a shared vision, and personal proficiency (Fillion et al., 2017). The NDPWI can respond on time to its clients if it implements the five core disciplines of a learning organisation.

\section{CONCLUSIONS}

The research aimed to explore the factors responsible for the delays in the execution of construction projects registered with the NDPWI by its client and suggest a concrete approach to their amelioration. As shown in Table 1, a sample was made of six projects registered with the NDPWI from the three regional offices between 2016 and 2020. As of December 2020, two of the projects are still at the planning/design stage, three are in the construction stage and one has been completed. Although the sizes of the projects were not identified, there is no doubt that the slow pace of execution has negative effects on the relationship between the clients and the NDPWI. Therefore, this research was justified, focusing on identifying the possible factors responsible for the slow pace of project delivery and proffering suitable solutions.

The factors responsible for the delays in construction project execution are effective client-management structure, project-management competencies, leadership, and systems thinking. They are classified as inhouse constraints. The others are consultant and contractor competencies; these two are classified as external constraints. The third cluster of factors is teamwork, which embraces all stakeholders in the construction project. Therefore, the first objective of this research has been achieved; the factors responsible for the delays have been identified, encapsulated in the themes, and classified. The second objective was to proffer solutions on how to ameliorate the negative effects of these delay factors. As a panacea to the problems identified, this research recommends that:

- The NDPWI should adopt a semi-decentralised management structure, encouraging the delegation of authority, semi-autonomy, and innovation in the regional offices.

- The training and retraining of PMs should be given prominence to improve their competency level.

- The PMs should be empowered to perform project coordination and enforce the penalty and reward clause in contractual conditions.

- Senior management should adopt the contextual use of the concept of performance management, demanding timely progress reports from the PMs, and holding them accountable for lapses in the execution. 
Furthermore, since this research was conducted in three out of the twelve regional offices, this research should be extended to all the regional offices of the NDPWI to obtain a nationwide picture. By doing so, it will be possible to effectively generalise the factors causing the delays in the execution of construction projects by the NDPWI and proffer long-term solutions.

\section{ACKNOWLEDGEMENTS}

The publication of the article for 11th International Conference on Engineering, Project, and Production Management - EPPM2021 was financed in the framework of the contract no. DNK/ SN/465770/2020 by the Ministry of Science and Higher Education within the "Excellent Science" programme.

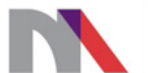

Ministry of Science and Higher Education Republic of Poland

\section{LITERATURE}

Aaltonen, K., \& Turkulainen, V. (2018). Creating relational capital through socialization in project alliances. International Journal of Operations \& Production Management, 38(6), 1387-1421.

Ahsan, K., \& Paul, S. K. (2018). Procurement issues in donor-funded international development projects. Journal of Management in Engineering, 34(6), 01-44.

Alsuliman, J. A. (2019). Causes of delay in Saudi public construction projects. Alexandria Engineering Journal, 58(2), 801-808.

Ansah, R. H., \& Sorooshian, S. (2018). 4P Delays in Project Management. Engineering, Construction and Architectural Management, 25(1), 62-76.

Baal, A., \& Outridge, D. (2020). Subsidiary project plan requirements for public construction projects in Trinidad and Tobago. The International Conference on Emerging Trends in Engineering and Technology (IConETech 2020).

Belton, I., MacDonald, A., Wright, G., \& Hamlin, I. (2019). Improving the practical application of the Delphi method in group-based judgment: A six-step prescription for a well-founded and defensible process. Technological Forecasting and Social Change, 147(1), 72-82.

Bodea, C-N., \& Purnus, A. (2016). FIDIC Contracts: Analysis of the Impact of General and Particular Conditions on the Financial Risk Management in Romanian Infrastructure Projects. Juridical Tribune Journal, 6(2), 167-181.
Braun, V., \& Clarke, V. (2016). (Mis) conceptualising themes, thematic analysis, and other problems with Fugard and Potts' (2015) sample-size tool for thematic analysis. International Journal of Social Research Methodology, 19(6), 739-743.

Cosa, S. (2020). Exploring the factors responsible for the delays in the execution of construction projects by the national department of public works and infrastructure in South Africa. Johannesburg: University of Johannesburg. Retrieved from http://hdl.handle. net/102000/0002

Darko, A., Zhang, C., \& Chan, A. P. (2017). Drivers for green building: A review of empirical studies. Habitat International, 60(1), 34-49.

Davis, K. (2018). Reconciling the views of project success: A multiple stakeholder model. Project Management Journal, 49(5), 38-47.

Deep, S., Bilal, M., \& Ahmad, S. (2017). A study of various factors affecting contractor's performance in lowest bid award construction projects. International Journal of Civil Engineering and Technology, 8(2), 28-33.

Durdyev, S., \& Hosseini, M. R. (2019). Causes of delays on construction projects: a comprehensive list. International Journal of Managing Projects in Business, 1(1), 01-28.

Fillion, G., Koffi, V., \& Ekionea, J-P. B. (2017). Peter Senge’s Learning Organization: A Critical View and the Addition of Some New Concepts to Actualize Theory and Practice. Journal of Organizational Culture, Communications and Conflict, 19(3), 73-102.

Fong, C. K., Avetisyan, H. G., \& Cui, Q. (2014). Understanding the Sustainable Outcome of Project Delivery. Methods in the Built Environment, Organization, Technology \& Management in Construction, 6(3), 1141-1155.

Franco, L. A., \& Nielsen, M. F. (2018). Examining group facilitation in situ: the use of formulations in facilitation practice. Group Decision and Negotiation, 27(5), 735-756.

Gambo, N., Said, I., \& Ismail, R. (2016). Influences of Cost Factors Affecting Technical Performance of Local Government Projects in Nigeria: A Partial Least Square-Structural Equation Modeling (PLS-SEM) Approach. Journal of Construction in Developing Countries, (21), 85-111.

Gebrehiwet, T., \& Luo, H. (2017). Analysis of Delay Impact on Construction Project Based on RII and Correlation Coefficient: Empirical Study. Procedia Engineering, 196, 366-374.

Gomes, C. F., \& Yasin, M. M. (2017). Toward promoting effective strategic performance: the relevance of the alignment of performance measurement and competitive strategic choices. International Journal of Business Excellence, 12(3), 329-350.

Gunduz, M., \& Abu Hassan, M. H. A. (2017). Mapping the industrial perception of delay data through importance rating. Arabian Journal for Science and Engineering, 42(1), 3799-3808.

Hurta, H., Jazouli, A., Koplyay, T., \& Motaghi, H. (2017). Mergers and acquisitions from the perspective of project management. Polish Journal of Management Studies, 15(2), 100-114. 
Janićijević, N. (2017). Organizational Models as Configuration of Structure, Culture, Leadership, Control and Change Strategy. Economic Annals, LXII(213), 67-91.

Jigeesh, N., \& Rao, N. S. N. (2015). Analysis and control of issues that delay pharmaceutical projects. Business: Theory and Practice, 16(3), 252-263. doi: 10.3846/ btp.2015.491

Knol, W. H., Slomp, J., Schouteten, R. L., \& Lauche, K. (2018). Implementing lean practices in manufacturing SMEs: testing 'critical success factors' using Necessary Condition Analysis. International Journal of Production Research, 56(11), 3955-3973.

Kuchta, D., Klaus-Rosińska, A., Ropuszyńska-Surma, E., \& Walecka-Jankowska, K. (2017). Threats to research projects across the project life cycle. Forum Scientiae Oeconomia, 5(3), 71-87. doi: 10.23762/FSO_vol5no3_17_5

Lee, T. R., \& Mouritsen, S. C. (2018). Judging Ordinary Meaning. The Yale Law Journal, 1(1),788-879.

Lindahl, G., \& Ryd, N. (2007). Clients' goals and the construction project management process. Emerald Group Publishing Limited, 25(3/4), 147-156.

Liu, L. (2020). Research on Performance and Decisionmaking Method of Project Management Mode. IOP Conference Series: Earth and Environmental Science, 526(1), 01-07.

Mahdi, I. M., Ebid, A. M., \& Khallaf, R. (2020). Decision support system for optimum soft clay improvement technique for highway construction projects. Ain Shams Engineering Journal, 11(1), 213-223.

Maslach, D., Branzei, O., Rerup, C., \& Zbaracki, M. J. (2018). Noise as signal in learning from rare events. Organization Science, 29(2), 225-246.

Mosly, I. (2016). Construction Project Delivery System Selection Framework: Professional Service Firms' Perspective. Journal of Civil Engineering and Architecture, 10(1), 368-378.

Mukhtar, M., Sudarmi, S., Wahyudi, M., \& Burmansah, B. (2020). The Information System Development Based on Knowledge Management in Higher Education Institution. International Journal of Higher Education, 9(3), 98-108.

Nijhuis, S., Vrijhoef, R., \& Kessels, J. (2018). Tackling Project Management Competence Research. Project Management Journal, 49(3), 62-81.

Ogbeifun E. (2018). Performance management as a tool for performance improvement in the management of built facilities. Journal of Construction Project Management and Innovation, 8(2), 1852-1871.

Ogbeifun E., Mbohwa, C., \& Pretorius, J. H. C. (2018). Fragmentation of capital development projects: A tool for job creation and skill development. Proceedings of the 34th Conference of the Association of Researchers in Construction Management (ARCOM), Belfast, UK, 717-726.

Ogbeifun, E., Mbohwa, C., \& Pretorius, J. H. C. (2016). Complementing a Delphi Exercise with a Focus Group Session. Proceedings of the 2016 IEEE International Conference on Industrial Engineering and Engineering Management (IEEM), Bali, Indonesia, 1269-1273.
Ogbeifun, E., Mbohwa, C., \& Pretorius, J. H. C. (2016a). Developing Key Performance Indicators using the Delphi Technique. FUTY Journal of the Environment, 10(1), 27-38.

Ogbeifun, E., Mbohwa, C., \& Pretorius, J. H. C. (2017). Achieving Consensus Devoid of Complicity: Adopting the Delphi Technique. International Journal of Productivity and Performance Management, 66(6), 766-779.

Okwir, S., Nudurupati, S. S., Ginieis, M., \& Angelis, J. (2018). Performance measurement and management systems: a perspective from complexity theory. International Journal of Management Reviews, 20(3), 731-754.

Oun, T. A. (2016). The Association of Knowledge Management and Project Management: An Enterprise-wide Approach Based on Stankosky's Four Pillar of Knowledge Management and PMI's Project Management Knowledge Areas. ProQuest Dissertations \& Theses Global.

Pal, R., Wang, P., \& Liang, X. (2017). The critical factors in managing relationships in international engineering, procurement, and construction (IEPC) projects of Chinese organizations. International Journal of Project Management, 35(7), 1225-1237.

Pourrashidi, R., Mehranpour, M., \& Nick, M. F. (2017). Human resources management: challenges and solutions. Helix, 8, 998-1001.

Rao, B. P. (2016). Delay Analysis of Construction Projects. Journal of IT and Economic Development, 7(1), 15-24.

Reefke, H., \& Sundaram, D. (2017). Key themes and research opportunities in sustainable supply chain management-identification and evaluation. Omega, 66(1), 195-211.

Rodriguez-Labajos, L., Thomson, C., \& O’Brien, G. (2016). Exploring the attributes and KPI's adopted by international healthcare providers to measure the performance of their estates at the strategic level. In Proceedings of the 32nd Annual ARCOM Conference, 2(1), 1213-1223.

Rosa, A. C. M., \& Broday, E. E. (2018). Comparative analysis between the industrial and service sectors: a literature review of the improvements obtained through the application of lean six sigma. International Journal for Quality Research, 12(1), 227-252.

Saunila, M. (2017). Understanding innovation performance measurement in SMEs. Measuring Business Excellence, 21(1), 1-16.

Shao, Z., Feng, Y., \& Hu, Q. (2017). Impact of top management leadership styles on ERP assimilation and the role of organizational learning. Information \& Management, 54(7), 902-919.

Sharma, S. P. (2017). US Government Program Managers' Competencies to Manage Satellite Acquisition Programs. Doctoral dissertation, Northcentral University.

Shaw, T. (2018). Sustainable Leadership: A Delphi Study. ProQuest LLC.

Shohet, I. M., \& Nobili, L. (2017). Application of key performance indicators for maintenance management of clinics facilities. International Journal of Strategic Property Management, 21(1), 58-7. 
Sierra-Varela, L. A., Yepes, V., \& Pellicer, E. (2018). A Review of Multi-Criteria Assessment of the Social Sustainability of Infrastructures. Journal of Cleaner Production, 187(1), 496-513.

Solomon, O. B., Adeniyi, O., \& Oluwaseyi, A. A. (2017). Investigation into the Causes of Delay in Land Acquisition for PPP Projects in Developing Countries. Journal of Engineering, Design and Technology, 15(4), 552-570.

Strasser, A. (2017). Delphi method variants in information systems research: Taxonomy development and application. Electronic Journal of Business Research Methods, 15(2), 120-133.

Szpilko, D. (2020). Foresight as a Tool for the Planning and Implementation of Visions for Smart City Development. Energies, 13(7), 1782. doi:10.3390/en13071782

Tan, Y., Xue, B., \& Cheung, Y. T. (2017). Relationships between main contractors and subcontractors and their impacts on main contractor competitiveness: An empirical study in Hong Kong. Journal of Construction Engineering and Management, 143(7), 01-12.

The Oak Ridge Associated Universities. Retrieved from https://www.orau.gov/

Varga-Atkins, T., McIsaac, J., \& Willis, I. (2017). Focus Group meets Nominal Group Technique: an effective combination for student evaluation? Innovations in Education and Teaching International, 54(4), 289300.

Yap, J. B. H., \& Skitmore, M. (2018). Investigating design changes in Malaysian building projects. Architectural Engineering and Design Management, 14(3), 218-238.

Zadeh, M. T., Dehghan, R., Ruwanpura, J. Y., Jerge, G., \& Ahadzie, D. (2016). An Index to Assess Project Management Competencies in Managing Design Changes. International Journal of Construction Engineering and Management, 5(1), 11-24. 